（9）衝摮試験む行つたが，これと折損破面との関係はは つきりしなかつた。

(10) 抗折試験により, 表面肌の状況の調查も出来ると思 われる。

(11) 疲労強度は大体, 抗張力, 硬度とに関保しているが 関保ない場合す相当多く，製鋼上の欠陷が影響してい る様代思われる。

(12) 脫炭は少くなつているが Ferrite 層が Band にな つているものもあり Ferrite の存在しない事が望ま Lい。

(13) 表面疵Uボルトゆる2による欠陷は非常に少く, 改 善されている。
即ち，上記に列挙した如く，何等かの欠陷が，板ばね を折損に導いているために，ばね材及び製作上の技術的 向上が望まれるが，本試験結果から特江重要な因子々な つているすのの早急な改善が望まれるのである。従つて 今これを述べれば，下記の墸点が挙げられる。

1. 先づ，自質のばね鋼を製作する。

2. 表面肌，表面疵を改善する。

3. 硬度ムラを少くし，規格硬度以內に招さめる。

4. 表面仃痕气の他四部を作らない核炕る。

5. ニツプを研究し局部的に当りの強いすのを作らな い樣纣る。

\title{
「ツル卷バネ及辨バネの改善」に関する研究
}

志 熊 平 治 郎*

\section{STUDIES ON IMPROVEMENT OF COILED SPRING}

Heijiro Shiguma

In order to improve the design and characteristics of coiled spring, the author and his cooperators have been investigating formulae, effects of surface condition and other stress problems. These investigations are now going on, and this paper is only a brief description of the results hitherto obtained.

1. On formula

In conventional formula, number of active turn is assumed to be constant. But in our investigation, it is variable with deflection of the spring as follows;

$$
n_{t}-n_{a}=a \delta+c=\left(a \frac{d D}{p}\right)\left(\frac{\delta}{n_{t}} \frac{p}{d D}\right)+c
$$

$\delta$ : deflection of spring,

D : mean coil diameter,

a, c : constants

and

$$
\begin{aligned}
& n_{l}-n_{a}=1.11 \sim 1.56 \\
& a \frac{d D}{p}=6.9 \sim 8.1
\end{aligned}
$$

are obtained experimentally.

2. On surface conditions and stressing, investigation of the following subjects are now going on :

a). Decarburization of Si-Mn spring steel.

b). Theoretical and experimental investigation of fatigue strength of case-hardened spring.

c). Improvement of torsional fatigue strength by shot-peening. $\mathbf{n}_{a}:$ number of active turn,

d : bar diameter,

p : pitch of spring 
の計画で，本報告は第 1 年度の研究の要約である。

研究の項目としては第 1 年沈㧊いては,
A，ッル卷バネの計算公式
B，爇好理的表面処理の影響
C, 応力的表面処理の影響

の 3 項を取上げた。

研究の実施に対しては東京工大の津村, 岡本両敎授他

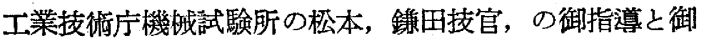
拹力を仰いげ。

本研究に対し通産省からの補助が正式に決定したのが 25 年11月で第 1 年度（昭和 25 年 3 月31日迄）の成果は多 くを得られていず，メンバーとしては第 2 年度の研究に 期待をかけ努力すしている。

ここに第 1 年度研究の要約を報告し諸賢の御批制と御 助言を希望しています。

A，ツル卷バネ計算公式の檢討

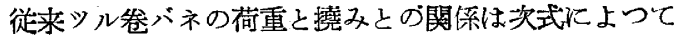
求められていた。

$$
\begin{aligned}
& \delta=\frac{8 n D^{3} P}{G d^{4}} \\
& こ こ に \cdot \delta: \text { 撓み }(\mathrm{mm}) \\
& n: \text { 有效卷数 } \\
& D: \text { ツル卷バネの中心湰 }(\mathrm{mm}) \\
& P: \text { 荷重 }(\mathrm{kg}) \\
& G: \text { 剪断彈性係数 }(\mathrm{kg} / \mathrm{mm}) \\
& d: \text { 線徍 }(\mathrm{mm})
\end{aligned}
$$

併しこの式は実験侹と喰違いを生ずるため実用上は線 径に応じてGの值を修正して使用されている。瓶し材料 力学上斯樣な修正は極めて不合理なことであり文事実種 々の往の丸鋼棒につき㿤験の結果むこのことを証明して いる。一方有効卷数 $\boldsymbol{n}$ は実用上は総卷数 $\mathrm{Nr}$ から一定 数 $1.5 〜 2.0$ を引いた值を使用しているがこの值の根拠 は乏しく、疑点がある。

ここに颃いて先づ 6 種類, 各 3 個計 18 個のバネにつき 正確に有効卷数を測定することに着手した，即ちバネに 或る荷重をかけた時の全斑みを $\delta$, 端末のコイルの影響 を受けない中央部の 3 ピッチの撓みを $\delta_{3}$ とし有効卷数 を次の樣に定義した。

$$
n=\frac{3 \delta}{\delta_{3}}
$$

この稊にして18個のバネにつき実験の結果を見ると， 各バネに対しても $n$ は一定値でなく或いは $(\mathrm{Nr}-\mathrm{n})$ は

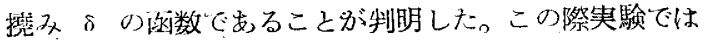
撓み $\delta$ と荷重 $P$ との関係が測定ざれていないので，た
とへ $G$ の値が $D / d$ 又は $d$ の值によつて变化すること があつてもそれは本測定值には影響を及ぼすことはない かくして実験の結果は $\left(\mathrm{N}_{r-n}\right)$ は大体 $\delta$ の一次式で表 わされ，無負荷時には $1.11 〜 1.56$, 全圧縮時には 2.00 ～2.31となることを示している。合 $\delta$ の一次式を

$\mathrm{Nr}-\mathrm{n}=a \delta+c$

$$
=\left(a \frac{d D}{p}\right)\left(\frac{\delta}{N r} \frac{p}{d D}\right)+c
$$

$\boldsymbol{p}:$ ピシチ

の如く扣き, 実験の結果を無次元表示をして胃れば，6 種類の中 2 種類の他は $\left(a \frac{d D}{p}\right)$ の値が $6.9 \sim 8.1$ となり 本均值が 7.3 となる。

以上の如く今回の央験により従来全く顧られなかつた 事実が明らかとなつたが，実験值のバラッキにより妥当 な結論の誘導を妨げている。これは実験に供したバネの 形状殊に端末部のコイルの状況が不齊であつたためと考 えられる。このため今後この点を注意の上実験用バネを 新たに製作し，同様な方法によつて上記の事項を再檢討 する。

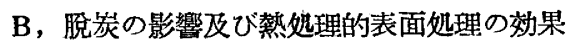

(1) $\mathrm{Si}-\mathrm{Nn}$ 鋼の脫炭廨について,

現在我国においてて車輛用ツル卷バネとして多くの $\mathrm{Si}$. Mn 鋼が使用されているが，一方この鋼種に対しては， 脫炭し易きこと及表面切欠感受性の大なることす知られ ている。ここに拀いて本鋼種を加熱する時に

a）脫炭を防止したるの

b）脫炭したあのを液体炭浴で復炭したすの

c）脫炭を防止したものに対し同样に炭したるの につて, 主として Jominy の方法により硬化能の変 化を調查し、これによつて脫炭の影響を檢べて見た。 この結果

1）激しく脫炭したものは復钮によつ‘脫炭前の性 質に回復しない。

2）脫炭は著しく疲労限を低下ざせ, 䏌或程度以上 脫炭すれば低下の程度は大して増加しない。

3）脫炭による疲学限の低下は復炭により著しく回 復され概ね脫炭しないるのと同等になる。

4）実験の結果は 2) の a), c）の計算値とよく一 致する。

等の結論が得られた。

C, 応力的表面処理の効果

応力的表面処理の中ッル卷バネの適用が容易でしかも その効果が顯蕫なものとしては先づショットピーニング 
加工が考えられる。ここに招いて取敢えずその効果の有 無或いはその程度の概略を知るため，試験片にショット ピーニング处理を施し，これをシエンク式疲労試駼機に より両振り据り疲労試験を行つてその效果老確めた。

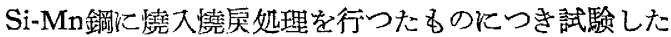
結果は，ショットピーニングを施さないすのが $39 \mathrm{~kg} /$ $\mathrm{mm}^{2}$ の疲労強度安有するに対し, 施したものは $45 \mathrm{~kg} /$ $\mathrm{mm}^{2}$ となり $15 \%$ 向上宗している。

\title{
小型時計ゼンマイ用鋼の材質に就て \\ 小柴 定 雄*
}

\section{ON THE MATERIALS FOR TIME PIECE SPRING}

\begin{abstract}
Sadao Koshiba
The superiority of the quality of materials is essential for a good time piece spring. Acco:dingly the quality of raw materials, composition, heat-treatment, micro-structure, surface finish etc. must be fully examined for making good springs.

The author has investigated influence of impurities, relationship between non-metallic inclusions and cleanliness, change of hardness and micro-structure with a rate of cold working and intermediate annealing, heat-treatment and mechanical properties on the spring steel sheet which had been made of good Masago iron sand.

The author has also investigated for purposes of reference, foreign and Japanese time piece springs which were obtained on the open markets.
\end{abstract}

\section{I 粕 言}

懷中時計或は腕時計等に用いられる小型ゼンマイはそ の厚みが，約 $0.15 \sim 0.060 \mathrm{~mm}$ の極め‘薄いもので，そ の材質は特に優れたるのが要求される。洔計ゼンマイ材 としては以前は殆んど欧米墸国殊汇瑞典より輸大せられ たすのであるが，終戦後これが在庫も少くなり，しかる 輸入す不可能であつた為，これが內地で製造することが 要請された。

弊社安来工場に於しは各方面の要望により当地方産出。 の真砂砂鉄を原料上して，エルー式電気弧光炬で熔製し これ熱間圧延により $2 \mathrm{~mm}$ のフープとなし，これを優 秀な冷間生延技術を有する特殊金属地延K K Vと種々の 厚みの薄板とし，試作し，各方面で使用した結果所期の

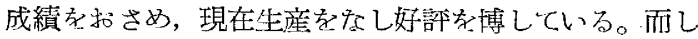
‘本文は従来列国及び国産のゼンマイ材江就て調查し， 又安来で種从研究を行つている結果より，時計ゼンマイ 材の材資に就て簢単に述べ，参考に資寸る次第で要る。

\section{II 時計ゼンマイ用銅の種類と性質}

時計ゼンマイとして具埆すべき條件は㺗性限が高く，
耐屈龳性が大きく，且つ衝擎及び度労に対して大なる抵

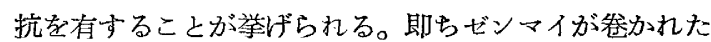
ときへたらず，トルクが大きく，且つ切れないことが必 要である。徒つて性能のよいゼンマイを得る為には，材 質, 組成, 蓺処理, 冷間加工, 顯微鏡組織, 表面仕上等 十分吟味しなけ机ばならない。即ち燐，硫黄及び銅等の 不純元素が少く, 又酸素, 水素, 窒素等の有害瓦斯す少 く，且つ非金属介在物の出来るだけ少いことが空ましい。 文偏析其他の有害な疵のないことす大切な事柄である。

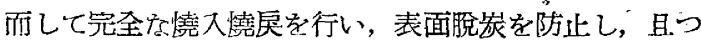
表面仕上る出来るだけ綿密に行い，厚及の公盖す少い事 が重要な事である。従つて原料鉄，熔解法，熱間並びに 冷間加工法，熱処理，仕上加工等各分野飞渡つ'て極めて 綿密な作業を行わねばなら奴。

時計ゼンマイ用堸は一般に柱時計，置時計用のるの之 懹中時計，腕時部用のるのとその組成を異にする。第 1 表は用途別に上るゼンマイ用鋼の概略の化学成分の範囲 を走す。

即ち一般ゼンマイ材としては C 0.8 1.0\% のものが

* 日立製作所安來工場治金研究所長 工博 